\title{
APSŪDZĒTO TIESĪBU VIENLĪDZĪBA LIKUMA UN TIESAS PRIEKŠĀ VIENKĀRŠOTAJOS PROCESOS
}

\section{EQUALITY OF ACCUSED PERSONS' RIGHTS BEFORE LAW AND COURT IN SIMPLIFIED PROCEEDINGS}

\author{
Jānis Maizīis, $M g$. iur. \\ Latvijas Universitātes Juridiskās fakultātes \\ Krimināltiesisko zinātṇu katedras vieslektors
}

\section{Summary}

The paper aims to present an opinion on the equality of rights of the accused person or persons who have the right to defence, before the court and the law in connection with the forms of completing the simplified criminal proceedings and includes a brief insight into the history and development of the simplified proceedings. To ensure the rights of accused persons before the court and within the framework of national legislation, the author proposes linking the simplified proceedings to particular Articles of the Criminal Law, initially - Article 180 of the Criminal Law. The author offers an approach where general procedure is followed as an exceptional procedure in situations where, due to objective reasons, it is impossible to complete the criminal proceedings in an urgent procedure within the set terms. Furthermore, the form for completing the criminal proceedings should be chosen at the moment of commencement of each particular criminal proceedings.

Atslēgvārdi: cilvēka tiesības, apsūdzētā tiesības, apsūdzēto vienlīdzība likuma priekšā, vienkāršotie procesi

Keywords: human rights, rights of the accused person, equality of accused persons before law, simplified proceedings

Latvijas Republikas Satversmes VIII nodal̦ā ir noteiktas cilvēka pamattiesības, kas ir kodols procesuālo garantiju īstenošanai un nodrošināšanai Latvijā. Vispirms jau Satversmes 90. pantā nostiprinātās tiesības ikvienai personai zināt savas tiesības un 91. pantā noteiktās vienlīdzības princips, kas ietver arī diskriminācijas aizliegumu, kā arī 92. pantā noteiktās ikvienas personas tiesības aizstāvēt savas tiesības un likumiskās intereses taisnīgā tiesā, ievērojot nevainīguma prezumpciju. ${ }^{1}$ Raksta mērḳis ir salīdzināt Satversmē noteiktās cilvēka pamattiesības ar apsūdzētā tiesībām Latvijas kriminālprocesuālajā kārtībā, izvērtējot apsūdzētā tiesības ietekmēt vienkāršoto kriminālprocesu izvēli un to sasaisti ar procesa virzītāja tiesībām un pienākumiem.

1 Latvijas Republikas Satversme: LV likums. Latvijas Vēstnesis, 01.07.1993., Nr. 43; Satversmes komentāri. VIII nodaļa. Cilvēka pamattiesības. Autoru kolektīvs prof. R. Baloža zinātniskā vadībā. Rīga: Latvijas Vēstnesis, 2011. 
Eiropas Cilvēka tiesību un pamatbrīvību aizsardzības konvencijas 6. pantā ir noteikts:

"Ikvienam ir tiesības, nosakot savu civilo tiesību un pienākumu vai jebkuras viņam izvirzìtās apsūdzības pamatotību krimināllietā, uz taisnīgu un atklātu lietas izskatīšanu saprātīgos termiņos neatkarīgā un objektīvā, ar likumu izveidotā tiesā. Tiesas spriedums pasludināms publiski, taču preses un publikas klātbūtne procesā var tikt aizliegta uz visu lietas izskatīšanas laiku vai tikai tās daḷu tikumības apsvērumu, sabiedriskās kārtības vai valsts drošības interesēs, ja to demokrātiskā sabiedrībā prasa nepilngadīgo intereses vai procesa dalībnieku privātās dzìves aizsardzība, vai arī tādā apmērā, kuru tiesa uzskata par absolūti nepieciešamu, ja īpašajos lietas apstākḷ os atklātība apdraudētu tiesvedības intereses.

2. Ikviens, kas tiek apsūdzēts noziedzīgā nodarījumā, tiek uzskatìts par nevainīgu, kamēr viṇa vaina nav pierādīta saskaṇā ar likumu.

3. Ikvienam, kas tiek apsūdzēts noziedzīgā nodarījumā, ir tiesības vismaz:

a. tikt nekavējoties, viņam saprotamā valodā un detalizēti, informētam par viņam izvirzītās apsūdzības raksturu un iemeslu;

b. uz laiku un līdzekḷiem, kas nepieciešami, lai sagatavotu savu aizstāvību;

c. aizstāvēt sevi pašam vai saṇemt paša izvēlēta aizstāvja juridisku palīdzību, vai, ja viņam trūkst līdzekḷu, lai algotu aizstāvi, saṇemt nozīmēta aizstāvja palìdzību par velti, ja tas nepieciešams tiesvedỉbas interesēs;

d. nopratināt vai panākt nopratināt apsūdzības lieciniekus un pieprasīt aizstāvības liecinieku klātbūtni un nopratināšanu ar tādiem pašiem nosacījumiem kā apsūdzības lieciniekus;

e. uz bezmaksas tulka pakalpojumiem, ja viņš nesaprot tiesā lietoto valodu vai nerunā tajā."2

Kriminālprocesa tiesību avoti tiek balstīti kā uz Cilvēka tiesību pamatbrīvību konvenciju, tā arī Latvijas Republikas Satversmi. ${ }^{3}$ Viens no Kriminālprocesa pamatprincipiem, kas noteikts Kriminālprocesa likuma (turpmāk - KPL) 8. pantā, ir vienlīdzības princips, kas nosaka vienotu procesuālo kārtību visām kriminālprocesā iesaistītajām personām neatkarīgi no šo personu izcelsmes, sociālā un mantiskā stāvokḷa, nodarbošanās, pilsonības, rases un sociālās piederības, attieksmes pret reliǵiju, dzimumu, izglìtības, valodas, dzivesvietas un citiem apstākliiem. KPL 14. panta otrajā daḷā noteikts, ka procesa virzìtājs izvēlas konkrētajiem apstākḷiem atbilstošāko kriminālprocesa veidu un nepię̧auj neattaisnotu iejaukšanos personas dzivēe un nepamatotus izdevumus, savukārt KPL 15. pantā noteikts, ka ikvienam ir tiesības uz lietas izskatīšanu taisnīgā, objektīvā un neatkarīgā tiesā. Minētie kriminālprocesa pamatprincipi atbilst Satversmē noteiktajam.

Egils Levits, izsakoties par līdztiesību likuma un tiesas priekšā un diskriminācijas aizliegumu Satversmes 91. panta kontekstā, skaidro:

"Lìdztiesības princips pats par sevi nav nosakāms, interpretācijā izmantojot tikai juridiskus argumentus. Līdztiesības princips savā klasiskajā formulējumā (kā Satversmes 91. panta 1. teikumā, iespējams, ir pats abstraktākais juridiskais formulējums, kāds normatīvajos aktos vispār pastāv. Arī visplašākā, t. i., teleolog̣iskā, interpretācija, aprobežojoties vienīgi ar juridisku argumentāciju, nevar

2 6. pants. Eiropas Cilvēka tiesību un pamatbrīvību aizsardzības konvencija: starptautisks līgums. Eiropas Padome, Pieņemts 04.11.1950., Latvija pievienojusies 27.06.1997. Latvijas Vēstnesis, 13.06.1997., Nr. 143/144 (858/859).

3 Kriminālprocesa likums: LV likums. Latvijas Vēstnesis, 11.05.2005. Nr. 74 (3232), 
sniegt pilnīgi drošu atbildi uz jautājumu, piemēram, vai sekmīgi studenti, kas saņem stipendiju, un nesekmīgi studenti, kas nesaṇem stipendiju, atrodas vienādās vai dažādās situācijās. Lai atbildētu uz šo jautājumu, ir grūti iztikt bez lietderības apsvērumiem un sabiedrības politisko tiesību ievērošanas (piemēram, kādām prioritātēm izmantot ierobežotos valsts finanšu resursus). Taču tādā gadijumā jau ir ļoti viegli ieslīdēt politiskā argumentācijā. Atdalīt juridisku no politiskas argumentācijas ir iespējams tikai nosacīti. Juridiska argumentācija primāri balstās uz juridiski dogmatiskām konstrukcijām, kas nav tieši atkarīgas no sabiedrības viedokḷa tieši konkrētā gadījumā. Protams, juridiskā dogmatika arī balstās uz sabiedrības priekšstatiem un vērtējumiem, taču tie jau ir daudz abstraktāki un nav vērsti uz konkrētā jautājuma izlemšanu."4

KPL 1. pantā noteiktajā mērḳī arī ir iekḷauta dogmatiska deklarācija, proti, likums nosaka tādu kriminālprocesa kārtību, kas nodrošina efektīvu Krimināllikuma (turpmāk - KL) normu piemērošanu un krimināltiesisko attiecību taisnīgu noregulējumu bez neattaisnotas iejaukšanās personas dzīvē. ${ }^{5}$ Kriminālprocesuālās kārtības mērķī, lai arī tieši nav formulēts, ir iekḷauts kriminālprocesuālās kārtības ekonomiskuma princips, ka valsts tēriņi kriminālprocesuālai kārtībai būtu jāpakḷauj arī izdarītā noziedzīgā nodarījuma smaguma pakāpei un mantiskā, fiziskā un morālā kaitējuma sekām. Vienkārši skaidrojot, tas nozīmē, ka valsts nosaka kriminālprocesuālo likumdošanu, kura dod iespēju tērēt proporcionālus līdzekl̦us noziedzīgu nodarījumu apkarošanas funkcijai. Vienīgi šai kārtībai ir jābūt ne tikai iespējai, bet arī procesa virzìtāja pienākumam, līdzīgās situācijās nodrošinot personām, kurām ir tiesības uz aizstāvību, un apsūdzētajiem vienlīdzīgas tiesības likuma un tiesas priekšā.

Viens no veidiem, kā īstenot vienlīdzīgas tiesības likuma un tiesas priekšā, ir noteikts KPL 21. pantā kā tiesības uz sadarbību, proti, persona, kurai ir tiesības uz aizstāvību, var sadarboties ar kriminālprocesa veikšanai pilnvarotu personu, lai sekmētu krimināltiesisko attiecību noregulējumu. Sadarbība var izpausties vienkāršāka procesa veida izvēlē, procesa norises veicināšanā, citu personu izdarìtu noziedzīgu nodarījumu atklāšanā, turklāt sadarbỉba iespējama jau no procesa uzsākšanas brīža līdz pat soda izpildei. Autors uzskata: lai cik paradoksāli tas arī nešksistu, šajā KPL normā ir iekḷautas vienlīdzīgas attieksmes princips pret personām, kurām ir tiesības uz aizstāvību, proti, tās ir iespējas vienlīdzīgi izmantot vienkāršoto procesu. Vienlaikus vienkāršoto procesu definīcija nav atrodama pašā KPL. Kriminālprocesa tiesību vadošās zinātnieces Latvijā - Ārija Meikališa un Kristīne Strada-Rozenberga -, apskatot vienkāršotos kriminālprocesa pabeigšanas veidus, norādījušas: "Mūsuprāt, pie vienkāršotajiem procesiem būtu pieskaitāmi šādi kriminālprocesa veidi, kas bija pazīstami gan KPK, gan ir iekḷauti KPL:

1) kriminālprocesa izbeigšana, atbrīvojot no kriminālatbildības - KPL 5-3. p., KPL 379. p.;

2) nosacīta kriminālprocesa izbeigšana - KPL 5-4. p., KPL 34. nodaḷa;

3) vienošanās process - KPK 19 a nodal̦a, 9 a nodaḷa, KPL 38., 49., 50. nodaḷa;

4) lietas izskatīšana tiesā bez pierādijumu pārbaudes - KPK 276-1. p., KPL 499. pants;

4 Levits E. Par līdztiesỉbu likuma un tiesas priekšā, un diskriminācijas aizliegumu. Par Satversmes 91. pantu. Latvijas Vēstnesis, 08.05.2003., Nr. 68; Kriminālprocesa likums: LV likums. Latvijas Vēstnesis, 11.05.2005., Nr. 74 (3232).

5 Ibid. 
5) saīsinātais process - KPK 9. sadal̦a, KPL 37. nodaḷa.

Kā arī pie vienkāršotajiem procesiem var pieskaitīt vēl divas papildu vienkāršotās formas, kas ir jauninājums KPL:

6) prokurora priekšraksts par sodu - KPL 35. nodal̦a;

7) process neatliekamības kārtībā - KPL 36. nodaļa."6

Tādā veidā Latvijā pakāpeniski tika ieviesta Eiropas Padomes Ministru komitejas rekomendācija Nr. (87) 18 par tiesas procesa vienkāršošanu, tā saukto vienkāršoto jeb saīsināto procesu, bet vienlaikus tā uzsver arī alternatīvu iespējas, tās saistot ar krimināllietās kompetento iestāžu un citu iesaistīto iestāžu iespējamu izlīgumu kā alternatīvu tiesvedībai. ${ }^{7}$ Autors norāda, ka tādējādi pēc būtības pakāpeniski tiek ieviesta kriminālprocesuālā kārtība, kurā personu par vainīgu var atzìt ne tikai tiesa, izejot pilnas iztiesāšanas procesuālās stadijas, bet arī citā likumā noteiktā kārtībā. Šāda pieeja jebkurā gadījumā respektē faktu un saglabā priekšnoteikumu, ka personu par vainīgu var atzìt tikai tiesa (piemēram, apstiprinot vienošanos), bet vainas atzī̌sanas situācijā, piekrītot vienkāršotam kriminālprocesa pabeigšanas veidam, personu var atzìt par vainīgu arī citā likumā noteiktā kārtībā. Minētās kriminālprocesuālās iespējas uzskatāmas par radikālu kriminālprocesuālās kārtības maiṇu, taču tā būtiski ir saistīta ar procesa virzìtāja izvēli - to piemērot vai ne. KPL 29. panta pirmās daļas 4. punktā ir noteikts izmeklētāja pienākums izvēlēties tādu kriminālprocesa veidu, kas nodrošina taisnīgu krimināltiesisko noregulējumu bez neattaisnotas iejaukšanās personas dzīvē un nepamatotiem izdevumiem. Viens no izmeklētāja tiešā priekšnieka pienākumiem ir noteikts KPL 31. panta otrās daḷas 3. punktā, pieprasot piešksirt procesuālās pilnvaras nepieciešamajam savā pakḷautībā esošo amatpersonu lokam, lai nodrošinātu kriminālprocesa veikšanu mērķtiecīgi un bez neattaisnotas novilcināšanas. KPL 31. panta otrās daḷas 4. punktā noteikts, ka izmeklētāja tiešajam priekšniekam ir pienākums dot norādījumus par izmeklēšanas virzienu un izmeklēšanas darbības veikšanu, ja procesa virzītājs nenodrošina mērḳtiecīgu izmeklēšanu, piel̦auj neattaisnotu iejaukšanos personas dzīvē vai vilcināšanos. Arī KPL 37. panta otrās daḷas 1. punktā noteikts uzraugošā prokurora pienākums dot norādījumus par procesa veida izvēli, izmeklēšanas virzienu un izmeklēšanas darbību veikšanu, ja procesa virzìtājs nenodrošina mērķtiecīgu izmeklēšanu un piẹ̦auj neattaisnotu iejaukšanos personas dzīvē vai vilcināšanos. Tādējādi autors secina, ka ar likuma normām būtībā ir noteiktas darba organizācijas prasības.

Pēc KPL pieņemšanas ir turpinājusies diskusija par vienkāršoto procesu efektivitāti, likums ir vairākkārt papildināts un grozīts. 2018. gada 20. jūnijā Saeima pieñēmusi kārtējos grozījumus KPL, kuri stājās spēkā 2018. gada 1. septembrī. ${ }^{8}$ Likuma grozījumos tiek attīstīta ideja par vienkāršotajiem procesiem, turklāt šie uzskatāmi par vieniem no būtiskākajiem grozījumiem KPL pēdējo gadu laikā. Šajos grozijumos tiek papildināts likuma 424. pants un noteikts jauns vienkāršotais process - paātrinātais process:

"424. pants. Paātrinātā procesa piemērošanas piel̦aujamība

Procesa virzìtājs var piemērot paātrināto procesu, ja:

1) noskaidrota persona, kas izdarījusi noziedzīgu nodarījumu;

6 Meikališa Ā., Strada-Rozenberga K. Kriminālprocess. Raksti. 2005-2010. Rīga: Latvijas Vēstnesis, 2010, 43. lpp.

7 Eiropas Padomes Ministru komitejas rekomendācija Nr. R(87)18 "Par dalībvalstu kriminālās justīcijas vienkāršošanu”, pieņemta Ministru komitejā 17.09.1987. ministru vietnieku 410. sanāksmē.

8 Grozijumi Kriminālprocesa likumā: LV likums. Latvijas Vēstnesis, 04.07.2018., Nr. 132 (6218). 
2) persona izdarījusi kriminālpārkāpumu, mazāk smagu vai smagu noziegumu;

3) izmeklēšanu iespējams pabeigt paātrinātajam procesam paredzētajā termiņā un apjomā."

Turpinās arī zinātnieku diskusijas par grozījumu būtību. Tā profesores Ā. Meikališa un K. Strada-Rozenberga izsaka savu viedokli:

"Izvērtējot jaunieviesto "paātrināto procesu", kopumā jāatzīst, ka izmainass, kas, kā tika prognozēts, kardināli uzlabos kriminālprocesu efektivitāti, nav notikušas, ir visai maz. Salīdzinot ar neatliekamības kārtības procesu un saīsināto procesu ar ieviesto paātrināto procesu, jāatzīst, ka pēdējais pēc būtības ir samiksēts abu iepriekšējo modelis (saīsinātais process + neatliekamības process tiesā) ar visai nelielām modulācijām. Faktiski būtiskākais ir tas, ka par sevišķ smagiem noziegumiem nevarēs tikt piemērots neviens vienkāršotais process izmeklěšanas laikā (agrāk saīsināto procesu varēja piemērot. Terminu saīsinājuma pirmstiesas procesā nav, faktiski izmeklēšanas termini ir pagarināti (līdz šim izmeklēšanai neatliekamỉbas kārtībā bija atvēlētas piecas darba dienas, saīsinātā procesa kārtībā - 10 dienas). Prokurora darbïbas termiņš - 10 dienas nav mainijies. Tiesai gan šobrīd visos gadijumos jāuzsāk lietas izskatîšana ilgākais 10 dienu termiṇā (agrāk saīsinātajā procesā lietas iztiesāšanas termiņš nebija noteikts)."

Autores izsaka arī viedokli, ka "Likumdevējs ir devis papildu iespējas izmeklēšanas iestādēm, atvieglojot procesuālo formu iespējami plašākam gadījumu lokam. Atliek vien jautājums - vai izmeklěšanas iestādes to izmantos? Un, ja izmantos, vai tam ir gatava prokuratūra un tiesa, kurām prognozējami skaitliski pieaugošā gadījumu lokā būs jānodrošina procesu veikšana ātrākos termiņos". ${ }^{10}$ Šajā kontekstā arī autors ir izteicies, ka viens no vienkāršoto procesu piemērošanas kritērijiem ir to piemērošanas termiṇi - "otra būtiska kritēriju grupa ir termiņi, kādos iespējams pabeigt pirmstiesas kriminālprocesu. Tie ir saīsinātais process un neatliekamības kārtỉba". ${ }^{11}$ Taču noteikti jāpavērtē arī prakse, to saistot ar statistiku, kāda tā ir bijusi pēdējos vairāk nekā 10 gados. Tāpat bijušās saīsinātā procesa, neatliekamības un spēkā esošās paātrinātā procesa normas jāizvērtē no personas, kurai ir tiesības uz aizstāvību, tiesībām uz vienlīdzību tiesas un likuma priekšā.

Latvijas Republikas prokuratūras statistika liecina, ka laikā no 2014. gada līdz 2017. gadam 13,8-15,7\% pabeigto kriminālprocesu bijuši tieši saīsinātie procesi un procesi neatliekamības kārtībā. Salīdzinājumam 2018. gada pirmajā pusē saīsinātais process un neatliekamības kārtība, kā arì paātrinātais process ir bijis 15\% gadijjumu no pabeigtajiem kriminālprocesiem (ietverot gan periodu pirms, gan pēc KPL grozijumiem). ${ }^{12}$ Tādējādi jāatzīst: lai gan salīdzinoši neliela, tomēr ik gadu arī stabila procentuālā daḷa no visiem pabeigtajiem kriminālprocesiem ir tieši saīsinātie procesi, procesi neatliekamības kārtỉbā un paātrinātie procesi.

Noteikti vērts ir arī analizēt, par kādiem noziedzīgiem nodarījumiem iespējams piemērot saīsināto procesu, kā arī to, vai un kādā kapacitātē šì iespēja tiek izmantota. Ģenerālprokurors Ëriks Kalnmeiers ir norādījis, ka, piemēram, KL 180. pantā paredzēto noziedzīgo nodarījumu ìpatsvars valstī 2018. gadā ir bijis

\footnotetext{
${ }^{9}$ Meikališa Ā., Strada-Rozenberga K. Pārmaiṇu laiks kriminālprocesā turpinās - 2018. gada 20. jūnija grozījumi Kriminālprocesa likumā. Jurista Vārds, 14.08.2018., Nr. 33 (1038).

10 Ibid.

${ }^{11}$ Maizītis J. Kritēriji kriminālprocesa vienkāršošanai. Aktuālas tiesību realizācijas problēmas. LU 69. konferences rakstu krājums. Rìga: LU Akadēmiskais apgāds, 2011, 415. lpp.

${ }^{12}$ Latvijas Republikas prokuratūras darbs pirmstiesas procesā. Statistika 2014.-2018. gadam. Pieejams: http://lrp.gov.lv/lv/noderigi/statistika [aplūkots 02.03.2019.].
} 
11317 noziedzīgi nodarījumi, tas ir par 1,5\% mazāk nekā 2017. gadā un veido $26,2 \%$ no visiem reǵistrētajiem noziedzīgajiem nodarījumiem valstī. ${ }^{13}$ Tātad aptuveni piektajai dal̦ai noziedzīgu nodarījumu ir salīdzinoši neliela sabiedriskās bīstamības pakāpe, tomēr līdz šim aizvien nav dekriminalizētas zādzības nelielos apmēros. Lai arī izmeklētāja, izmeklētāja tiešā priekšnieka un uzraugošā prokurora pienākumi ir saistīti ar vienkāršoto procesu izvēli, pienākuma nepildīšanai nav nekādu seku - tas nozīmē, ka pārāk liela ir attiecīgā procesa virzìtāja diskrecionārā vara, kas ietekmē personas, kurai ir tiesības uz aizstāvību, tiesības uz vienlīdzību tiesas un likuma priekšā. Autora ieskatā to apliecina visi attiecīgo KPL vienkāršoto pantu formulējumi.

379. pants. Kriminālprocesa izbeigšana, atbrīvojot personu no kriminālatbildības

“(1) Izmeklētājs ar uzraugošā prokurora piekrišanu, prokurors vai tiesa var izbeigt kriminālprocesu, ja: [..]”

415. pants. Kriminālprocesa izbeigšana, nosacīti atbrīvojot no kriminālatbildības

“(1) Ja prokurors, ņemot vērā izdarītā noziedzīga nodarījuma raksturu un radìto kaitējumu, personu raksturojošos datus un citus lietas apstākḷus, iegūst pārliecību, ka apsūdzētais turpmāk neizdarīs noziedzīgus nodarījumus, prokurors var kriminālprocesu izbeigt, nosacīti atbrīvojot no kriminālatbildības."

420. pants. Prokurora priekšraksta par sodu piemèrošanas piel̦aujamība

“(1) Ja persona izdarījusi kriminālpārkāpumu, mazāk smagu noziegumu vai smagu noziegumu, par kuru paredzēts brīvības atṇemšanas sods līdz pieciem gadiem, un prokurors, ņemot vērā izdarītā noziedzịga nodarījuma raksturu un radìto kaitējumu, personu raksturojošus datus un citus lietas apstākḷus, ir guvis pārliecỉbu, ka šai personai nevajadzētu piemērot brīvības atņemšanas sodu, taču to nevar atstāt nesodītu, viņš var pabeigt kriminālprocesu, sastādot priekšrakstu par sodu."

\section{4. pants. Paātrinātā procesa piemērošanas piel̦aujamība}

"Procesa virzìtājs var piemērot paātrināto procesu, ja:

1) noskaidrota persona, kas izdarījusi noziedzīgu nodarījumu;

2) persona izdarījusi kriminālpārkāpumu, mazāk smagu vai smagu noziegumu;

3) izmeklēšanu iespējams pabeigt paātrinātajam procesam paredzētajā termiņā un apjomā.”

433. pants. Pamats vienošanās piemērošanai

"(1) Prokurors pēc savas paša, apsūdzētā un viṇa aizstāvja iniciatīvas var slēgt vienošanos par vainas atzīšanu un sodu, ja ir noskaidroti apstākḷi, kas attiecas uz pierādīšanas priekšmetu, un apsūdzētais piekrīt viṇam inkriminētā nodarījuma apjomam, kvalifikācijai, radītā kaitējuma novērtējumam un vienošanās procesa piemērošanai."

Vārds "var" visās minētajās KPL normās apstiprina procesa virzītāja izvēles brīvību un neveicina personu, kurām ir tiesības uz aizstāvību, vienlīdzību tiesas un likuma priekšā ne tikai iztiesāšanas termiṇu kontekstā, bet arī vērtējot, kurā kriminālprocesa stadijā notiek krimināltiesisko attiecību noregulējums līdzīgās situācijās, īpaši par noziedzīgiem nodarījumiem, kuriem nav liela sabiedriskā bīstamība, un tas veicina apsūdzēto nevienlīdzību. Būtībā tā sauktās vispārējās kriminālprocesuālās kārtības kā likumīgas alternatīvas pastāvēšana attiecībā uz visiem vienkāršotajiem procesa pabeigšanas veidiem veicina šo faktisko apsūdzēto

${ }^{13}$ Ģenerālprokurora Ē. Kalnmeiera pārskats par prokuratūras darbu 2018. gadā. Pieejams: http://lrp.gov. lv/lv/noderigi/gada-parskati [aplūkots 01.03.2019.]. 
nevienlīdzību. Šāda situācija mudina autoru uzdot jautājumu - kādi ir iespējamie risinājumi?

Autors uzskata, ka nekādā ziṇā nav jāatsakās no vienkāršotajiem kriminālprocesa pabeigšanas veidiem, bet, lai likvidētu vai sākotnēji mazinātu nevienlīdzību, ir jāpārskata vienkāršoto kriminālprocesa pabeigšanas veidu kritēriji. Pašlaik vienkāršotie kriminālprocesa pabeigšanas veidi ir pakārtoti kriminālprocesa pabeigšanas stadijai, izmeklēšanas, kriminālvajāšanas un iztiesāšanas termiņiem, kā arī noziedzīga nodarījuma smaguma pakāpei: kriminālpārkāpums; mazāk smags; smags un sevišḳi smags. Autora ieskatā, lai mazinātu apsūdzēto faktisko nevienlīdzību tiesas un likuma priekšā, kas saistīta ar pārāk lielo procesa virzìtāju vienkāršoto procesu izvēles brīvību, atseviškşi kriminālprocesa pabeigšanas veidi saistāmi nevis ar noziedzīga nodarījuma smaguma pakāpi, bet drīzāk ar konkrētu KL pantu uzskaitījumu KPL. Tā, piemēram, par KL 180. pantā paredzēto noziedzīgo nodarījumu kriminālprocesa pabeigšana piemērojama tikai paātrinātā procesa kārtībā vai personu atbrīvojot no kriminālatbildības. Vispārējā kārtība būtu iespējama nevis kā pastāvīgs pamatprincips, bet izṇēmums tikai pēc izvērtēšanas un tādā gadījumā, ja kādu objektīvu apstākḷu dēḷ nevarēs ievērot KPL noteiktos termiṇus. Tas autora ieskatā varētu būt uzraugošā prokurora atzinums vienas dienas laikā, kad uzraugošais prokurors nozīmēts un par konkrēto uzraugošo prokurora vārdu un uzvārdu darīts zināms izmeklētājam. Tādā veidā tiktu pastiprināta arī prokurora kā uzraudzītāja funkcija un prokurors tiktu tieši iesaistīts vienkāršotā procesa izvēlē no kriminālprocesa uzsākšanas brīža. Tā tiktu garantēta lielāka to personu procesuālā vienlīdzība tiesas un likuma priekšā, kurām ir tiesības uz aizstāvību.

\section{Kopsavilkums}

1. Autora ieskatā ir pamats diskutēt par to, kā vienkāršotajos kriminālprocesos tiek ievērots kriminālprocesuālās vienlīdzības princips tiesas un likuma priekšā.

2. Kriminālprocesuālās vienlīdzības princips arī vienkāršotajos procesos definējams kā kriminālprocesa pamatprincips.

3. Paātrinātais kriminālprocesa pabeigšanas veids saistāms ar konkrētiem KL pantiem. Tādējādi sākotnēji būtu jānoteic, ka pēc KL 180. panta uzsāktos kriminālprocesus iespējams pabeigt, tikai atbrīvojot no kriminālatbildības vai paātrinātā procesa kārtībā. Citiem KL pantiem saistībā ar konkrētu pabeigšanas veidu nepieciešama papildu pētniecība. Kritēriju maiṇai jābūt pakāpeniskai, modulējot prakses rezultātus.

4. Sākotnēji vispārējā kārtība ir jānosaka kā iznēēmuma iespēja attiecībā par noziedzīgajiem nodarījumiem, kas paredzēti KL 180. pantā. Piemēram, tā iespējama pēc uzraugošā prokurora akcepta dienu pēc kriminālprocesa uzsākšanas, izvērtējot objektīvos lietas apstākḷus, sarežǵìtību, piemēram, nepieciešamību izdarìt ekspertīzes u. tml.

5. Vienkāršoto pabeigšanas veidu izvēles mērķis saistāms ne ar izvēles iespējām, bet izṇēmumiem attiecībā uz noziedzīgiem nodarījumiem ar nelielu sabiedrisko bīstamību. 